\title{
Mechanical flower thinning in peach trees
}

\author{
Caroline Farias Barreto ${ }^{1}$, Luis Eduardo Correa Antunes ${ }^{2}$, Letícia Vanni Ferreira ${ }^{3}$, \\ Renan Navroski ${ }^{1}$, Jorge Atílio Benati ${ }^{1}$, José Francisco Martins Pereira ${ }^{2}$
}

\begin{abstract}
In cultivation of peaches, thinning is conventionally performed on fruits by hand, and needs to be done in a short time and with specialized labor, which increases the operational costs of this practice. Mechanical thinning can be an alternative to manual fruit thinning. Thus, the objective of this study was to evaluate the effect of mechanical flower thinning with different equipment in advanced peach orchard. The experiment was conducted in 2016 and 2017, combining advanced selections of peach trees and thinning methods. The evaluated variables were percentage of flowers thinning, thinning time, fruit number per plant, plant production, estimated yield, average fruit mass and fruit diameter class. Flower mechanic thinning alters the yield index of peach trees. Mechanical thinning on peach trees was efficient in flower thinning and reduced the practice execution time. Therefore, mechanical thinning is an alternative to the manual fruit thinning of peach trees.
\end{abstract}

Index terms: Prunus persica, flower removal, effective fruiting, thinning cost.

\section{Raleio mecânico de flores em pessegueiros}

\begin{abstract}
Resumo - Na produção de pêssegos, o raleio é realizado convencionalmente nos frutos, de forma manual, necessitando ser realizada num curto período de tempo e com mão de obra especializada, o que eleva os custos operacionais desta prática. O raleio mecânico pode ser uma alternativa ao raleio manual de frutos. Deste modo, o objetivo deste trabalho foi avaliar o efeito do raleio mecânico em flores, com distintos equipamentos, em seleções avançadas de pessegueiros. O experimento foi conduzido nos anos de 2016 e 2017, combinando-se seleções avançadas de pessegueiros e métodos de raleio. As variáveis avaliadas foram: percentagem de raleio de flores, tempo de raleio, número de frutos por planta, produção por planta, produção estimada, massa média dos frutos e classe de diâmetro dos frutos. O raleio mecânico de flores altera os índices produtivos dos pessegueiros. O raleio mecânico em pessegueiros foi eficiente no raleio de flores e reduziu o tempo de execução da prática. Portanto, o raleio mecânico de flores é uma alternativa ao raleio manual de frutos de pessegueiros.
\end{abstract}

Termos para Indexação: Prunus persica, remoção de flores, frutificação efetiva, custo de raleio.

Received: March 18, 2019

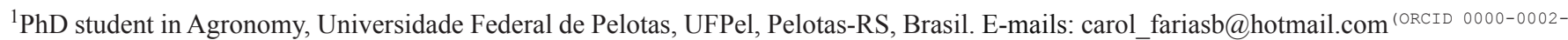
5568-5305); navroski@outlook.com (ORCID 0000-0002-7854-6172); jorgeatiliobenati@hotmail.com (ORCID 0000-0002-5970-9175)

${ }^{2}$ Researcher, Embrapa Clima Temperado, EMBRAPA, Pelotas-RS, Brasil. E-mails: luis.antunes@embrapa.br ${ }^{(0 R C I D ~ 0000-0002-0341-1476)}$; jose.fm.pereira@embrapa.br(ORCID 0000-0001-6172-0747)

${ }^{3} \mathrm{PhD}$ in Agronomy, Instituto Federal de Educação, Ciência e Tecnologia do Rio Grande do Sul, Ibirubá-RS, Brasil. E-mail: letivf@hotmail. $\left.\operatorname{com}^{(O R C I D} 0000-0002-1888-7514\right)$ 


\section{Introduction}

Peach trees produce abundant bloom under favorable cultivation conditions, being able to fix more fruits than the plant can support (PEREIRA and RASEIRA, 2014; GIOVANAZ et al., 2016), causing greater competition among fruits and also with vegetative growth, water and nutrients. In order to avoid excess fruit on plants, the amount per tree should be regulated. This adjustment may be by thinning so that fruits of adequate size are obtained for commercial acceptance (GIOVANAZ et al., 2016; OLIVEIRA et al., 2017).

In addition to removing the excess number of fruits from the plant, so that does not impair productivity, thinning is an important cultural practice in peach quality, which improves fruit color and size, and eliminates damaged and/or diseased fruits (PEREIRA and RASEIRA, 2014; OLIVEIRA et al., 2017).

Fruit thinning in peach trees is mainly done manually between 40 and 50 days after full bloom, but this practice needs to be performed in a short period, requiring high labor demand and resulting in high production cost (MCARTNEY et al., 2012; SIMÕES et al., 2013; OLIVEIRA et al., 2017). As an alternative to Manual fruit thinning in peach trees, studies have been conducted with chemical thinning (GIOVANAZ et al., 2016; BARRETO et al., 2018; FARIAS et al., 2019) and mechanical (MARTIN-GORRIZ et al., 2011; SIMÕES et al., 2013). Among the advantages of mechanical thinning stands out the possibility of thinning in less time compared to fruits manual thinning (MARTIN et al., 2010; MARTINGORRIZ et al., 2011; MILLER et al., 2011).

Mechanical thinning in peach trees has been adopted in several countries such as Spain, Portugal, Canada and the United States (MILLER et al., 2011; MARTIN-GORRIZ et al., 2011; SIMÕES et al., 2013; SAUERTEIG; CLINE, 2013). However, in Brazil the information is still scarce, requiring studies to develop this technology that can actually be used in orchards. The mechanization of thinning enables the peach producer to be profitable, as well as assisting in the scarcity of labor in the rural area.

In this context, the objective of this study was to evaluate the effect of mechanical thinning on flowers with different equipment in advanced peach trees selections (Prunus persica).

\section{Material and methods}

The experiment was conducted in the 2016 and 2017 harvests in the experimental area of Embrapa Clima Temperado, in the city of Pelotas, Rio Grande do Sul, Brazil. The Capdeboscq rootstock was used for grafting the Cascata 1513, Cascata 1067 and Cascata 1429 crowns, which are advanced selections from Embrapa Temperate Climate breeding program. Both cultivars have white pulp and are intended for fresh consumption. In the orchard, the spacing adopted between plants was $1.5 \mathrm{~m} \times 5.0 \mathrm{~m}$, with a planting density of 1,333 plants per hectare.

The average temperature and average precipitation during the experiment period were collected from the Embrapa Climate Temperate weather station (Figure 1). The cold hours (temperatures below or equal to $7.2^{\circ} \mathrm{C}$ )
2016

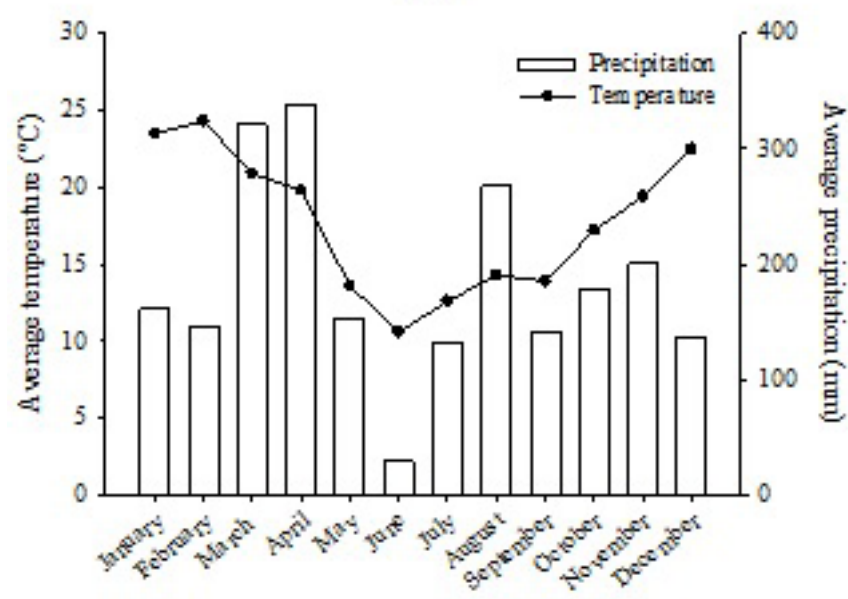

2017

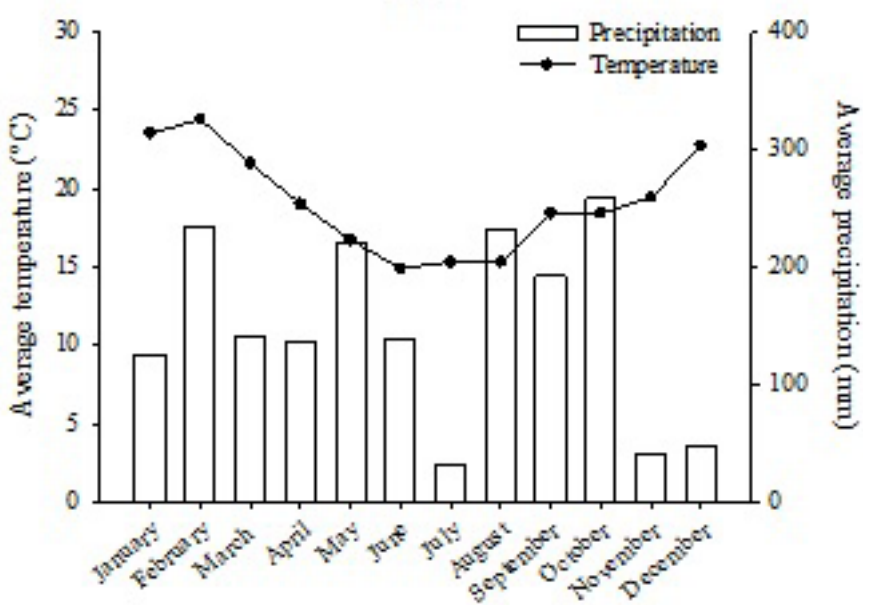

Figure 1 - Average temperature and precipitation of 2016 and 2017 in the municipality of Pelotas of the Embrapa Temperate Climate experimental station, RS, Brazil. 
recorded in 2016 and 2017 were 172 and 77 cold hours respectively.

The experimental design used was randomized blocks, $3 \times 3$ factorial scheme ( 3 thinning methods and 3 peach genotypes), with three replications, each repetition composed of two plants. The thinning methods used in this experiment were: fruits manual thinning 40 days after full bloom; mechanical flower thinning with a vibrating equipment, Carpa Electro ${ }^{\circledR}$ brand, in full bloom; and mechanical flower thinning with a trimmer, Sthil brand, in full bloom. The manual thinning was performed leaving the fruits $10 \mathrm{~cm}$ to $15 \mathrm{~cm}$ apart. The full bloom of peach trees 'Cascata 1513' selection occurred on 08/08/2016 and 07/31/2017, the 'Cascata 1067' selection on $08 / 08 / 2016$ and $07 / 31 / 2017$ and the 'Cascata 1429 ' selection on 08/08/2016 and 08/04/2017.

The mechanical thinning was performed by the manual device Carpa Electro $^{\circledR}$, which has a $20 \mathrm{~cm}$ long rotary rod with flexible rubber rings that is attached to a portable battery and the trimmer machine Sthil brand consisting of a gasoline engine, $1.5 \mathrm{~m}$ rod and a pair of $0.39 \mathrm{~m}$ long claws.

The evaluated variables were $\%$ of thinning, determined in four branches previously randomly selected in each plant and counting the number of flowers or fruits before thinning and the number of flowers or fruits at harvest (\%); number of fruits per plant, obtained by counting the fruits on each plant in the harvest (fruits plant $\left.^{-1}\right)$; production per plant $\left(\mathrm{kg} \mathrm{plant}^{-1}\right)$; estimated yield per hectare $\left(\mathrm{t} \mathrm{ha}^{-1}\right)$; thinning time, determined by the time spent performing each thinning treatment, timed via digital clock (minutes plant ${ }^{-1}$ ).

The peaches were harvested on 11/10/2016 and $11 / 14 / 2017$ in the 'Cascata 1513' selection, on 11/30/2016 and $11 / 24 / 2017$ in the 'Cascata 1067 ' selection and on 11/30/2016 and 11/20/ 2017 in the 'Cascata 1429' selection. After harvesting, 50 fruits were randomly taken to perform the average mass determined by weighing the fruits on a digital scale and the results expressed in grams $(\mathrm{g})$; the percentage distribution of fruits in terms of size was evaluated and divided into four classes: $<55 \mathrm{~mm}$, $55 \mathrm{~mm}$ to $<60 \mathrm{~mm}, 60 \mathrm{~mm}$ to $<65 \mathrm{~mm}$ and $>65 \mathrm{~mm}$.

Data were submitted to analysis of variance and analysis of means by Tukey test at $5 \%$ probability with the support of Sisvar software, version 5.6 (FERREIRA, 2014).

\section{Results and discussion}

In 2016 harvest, there was interaction among the studied factors (genotypes and thinning method) for $\%$ of flower and fruit thinning, yield per plant and estimated yield (Table 1). In this harvest, there was no significant difference in the percentage of thinning between the mechanically performed operation with the Carpa Electro equipment and the one performed manually, in the three evaluated genotypes. However, a smaller percentage of thinning was observed in the 'Cascata 1067' selection $(33.84 \%)$ when the trimmer was used, in relation to the other peach trees selections. The Carpa Electro ${ }^{\circledR}$ and trimmer equipment caused a higher percentage of thinning in the 'Cascata 1513' and 'Cascata 1429' selections when compared to the manually thinning, but did not differ from the 'Cascade 1067' selection.

In 2017 harvest, there were no significant differences in the percentage of flower thinning among the three peach genotypes, with values ranging from $41.44 \%$ to $55.81 \%$ for 'Cascade 1067' and 'Cascade 1429', respectively. Among the methods employed, the highest percentages of thinning were observed with the use of Carpa Electro ${ }^{\circledR}$ equipment and the trimmer when compared to manual thinning (Table 2).

In this study, the flower thinning percentages ranged from $33.84 \%$ to $61.73 \%$, regardless of the equipment used. This percentage of flower thinning is close to the values reported by Sauerteig and Cline (2013) who eliminated in the peach trees mechanical thinning approximately $42 \%$ to $75 \%$ of flowers and by Schupp et al. (2008) that recommend to eliminate $50 \%$ to $60 \%$ of flowers in mechanical thinning. In general, it can be observed in this study that the use of the equipment demonstrated efficiency in performing the overthrow of flowers and providing the execution of thinning on peach trees.

Mechanical flower thinning with the trimmer, although not significantly differing from the thinning performed with the Carpa Electro ${ }^{\circledR}$ equipment, provided an increase in production per plant and estimated peaches from the 'Cascata 1513' and 'Cascata 1067' selections compared to the fruits manual thinning in the 2016 harvest (Table 1). According to El-Boray et al. (2012), flower thinning may allow greater distribution of reserves for cell division during the fruit growth phase, thus reducing the initial competition for carbohydrates.

However, mechanical flower thinning in peach trees of the 'Cascata 1429' selection presented lower yield in 2016 harvest, regardless of the equipment used (Table 1), due to the lower number of fruits found in this selection (Table 3). Although this genotype had fruits with larger mass and diameter $(>65 \mathrm{~mm})$, the yield did not correspond in the same way due to the smaller number of fruits per plant (Table 3 and Figure 2). 
Table 1 - Interaction among thinning methods and peach genotypes on a $\%$ of thinning, average yield per plant and estimated yield per hectare in 2016, in the municipality of Pelotas, Rio Grande do Sul, Brazil.

\begin{tabular}{|c|c|c|c|}
\hline & \multicolumn{3}{|c|}{2016} \\
\hline & Manual fruit thinning & Carpa Electro $^{\circledR}$ & Trimmer \\
\hline & \multicolumn{3}{|c|}{ Thinning (\%) } \\
\hline Cascata 1513 & $38.13 \mathrm{aB}$ & $59.45 \mathrm{aA}$ & $57.50 \mathrm{aA}$ \\
\hline Cascata 1429 & $32.72 \mathrm{aB}$ & $57.23 \mathrm{aA}$ & $61.73 \mathrm{aA}$ \\
\hline Cascata 1067 & $34.12 \mathrm{aA}$ & $48.11 \mathrm{aA}$ & $33.84 \mathrm{bA}$ \\
\hline $\mathrm{CV}(\%)$ & \multicolumn{3}{|c|}{15.61} \\
\hline & \multicolumn{3}{|c|}{ Production per plant $(\mathrm{Kg})$} \\
\hline Cascata 1513 & $13.01 \mathrm{aB}$ & $16.31 \mathrm{aAB}$ & $18.20 \mathrm{aA}$ \\
\hline Cascata 1429 & $10.55 \mathrm{aA}$ & $7.34 \mathrm{cB}$ & $9.64 \mathrm{bA}$ \\
\hline Cascata 1067 & $11.38 \mathrm{aB}$ & $12.65 \mathrm{bAB}$ & $14.98 \mathrm{aA}$ \\
\hline CV (\%) & \multicolumn{3}{|c|}{13.42} \\
\hline & \multicolumn{3}{|c|}{ Estimated Production $\left(\mathrm{t} \mathrm{ha}^{-1}\right)$} \\
\hline Cascata 1513 & $17.35 \mathrm{aB}$ & $21.74 \mathrm{aAB}$ & $24.26 \mathrm{aA}$ \\
\hline Cascata 1429 & $14.06 \mathrm{aA}$ & $9.78 \mathrm{cB}$ & $12.86 \mathrm{bA}$ \\
\hline Cascata 1067 & $15.17 \mathrm{aB}$ & $16.87 \mathrm{bAB}$ & $19.97 \mathrm{aA}$ \\
\hline $\mathrm{CV}(\%)$ & & 13.42 & \\
\hline
\end{tabular}

C.V. (\%) Coefficient of variation. * Averages followed by distinct lowercase letters in the same column and averages followed by distinct uppercase letters in the same row differ by Tukey test at $5 \%$ probability of error.

Table 2 - Percentage of flower thinning, average yield per plant and estimated yield per hectare in 2017, in the municipality of Pelotas, Rio Grande do Sul, Brazil.

\begin{tabular}{lccc}
\hline & \multicolumn{4}{c}{2017} \\
Genotype & $\begin{array}{c}\text { Flower } \\
\text { thinning }(\%)\end{array}$ & $\begin{array}{c}\text { Average production } \\
\text { per plant }(\mathrm{Kg})\end{array}$ & $\begin{array}{c}\text { Estimated } \\
\text { Production } \\
\left(\mathrm{t} \mathrm{ha}^{-1}\right)\end{array}$ \\
\hline Cascata 1513 & $48.69 \mathrm{~ns}$ & $13.08 \mathrm{a}$ & $17.44 \mathrm{a}$ \\
Cascata 1429 & 55.81 & $11.61 \mathrm{~b}$ & $15.48 \mathrm{~b}$ \\
Cascata 1067 & 41.44 & $11.03 \mathrm{~b}$ & $14.71 \mathrm{~b}$ \\
\hline Thinning Method & & $11.79 \mathrm{~ns}$ & $15.72 \mathrm{~ns}$ \\
\hline Manual fruit thinning & $27.59 \mathrm{~b}$ & 11.96 & 15.94 \\
Carpa Electro $^{\circledR}$ & $52.21 \mathrm{a}$ & 11.98 & 15.97 \\
Trimmer & $55.14 \mathrm{a}$ & 21.98 & 21.98 \\
\hline CV (\%) & 22.48 & &
\end{tabular}

C.V. (\%) Coefficient of variation. * Averages followed by distinct lowercase letters in the column differ from each other by the Tukey test at $5 \%$ probability of error. * ns (not significant) at $5 \%$ probability of error.

Table 3- Number of fruits and average fruit mass of three peach genotypes submitted to different thinning methods in 2016 and 2017, in the city of Pelotas, Rio Grande do Sul, Brazil.

\begin{tabular}{lrrrrr}
\hline & \multicolumn{3}{c}{ Number of fruits per plant } & \multicolumn{3}{c}{ Average fruit mass (g) } \\
\hline \multicolumn{1}{c}{ Genotype } & 2016 & 2017 & 2016 & \multicolumn{1}{c}{2017} \\
\hline Cascata 1513 & $218.42 \mathrm{a}$ & $195.08 \mathrm{a}$ & $79.19 \mathrm{c}$ & $69.57 \mathrm{c}$ \\
Cascata 1429 & $76.15 \mathrm{c}$ & $55.08 \mathrm{c}$ & $129.79 \mathrm{a}$ & $130.54 \mathrm{a}$ \\
Cascata 1067 & $150.23 \mathrm{~b}$ & $118.08 \mathrm{~b}$ & $94.53 \mathrm{~b}$ & $95.23 \mathrm{~b}$ \\
\hline Thinning method & \multicolumn{7}{l}{} & & \\
\hline Manual fruit thinning $_{\text {Carpa Electro }}^{\circledR}$ & $124.16 \mathrm{~ns}$ & $104.80 \mathrm{~ns}$ & $104.14 \mathrm{~ns}$ & $112.84 \mathrm{~ns}$ \\
Trimmer & 158.30 & 128.09 & 95.32 & 85.52 \\
\hline CV (\%) & 162.34 & 136.06 & 95.62 & 96.97 \\
\hline
\end{tabular}

C.V. (\%) Coefficient of variation. * Averages followed by distinct lowercase letters in the column differ from each other by the Tukey test at $5 \%$ probability of error. ${ }^{*}$ ns (not significant) at $5 \%$ probability of error. 

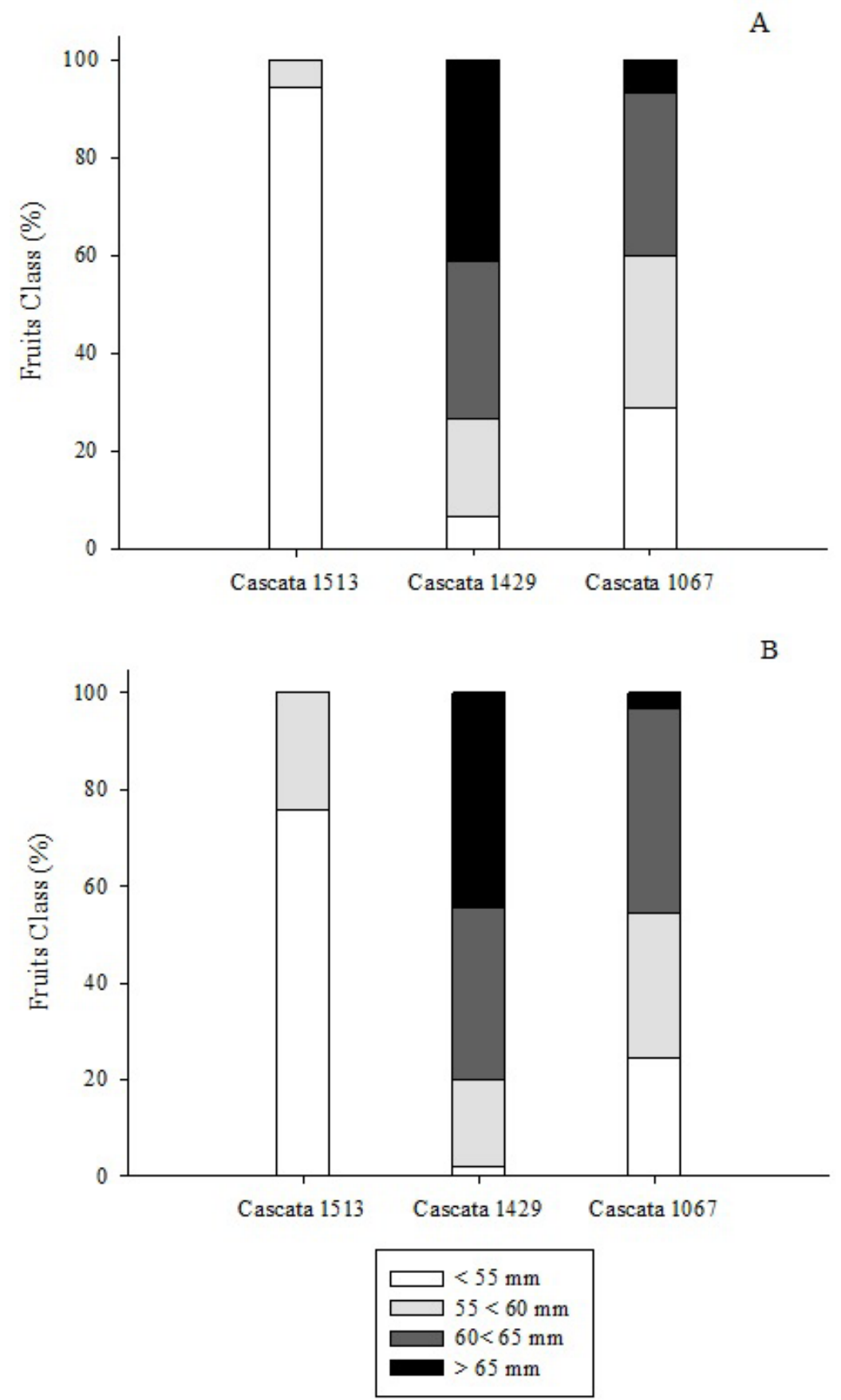

Figure 2 - Fruits Class by diameter $<55 \mathrm{~mm}, 55 \mathrm{~mm}$ to $<60 \mathrm{~mm}, 60 \mathrm{~mm}$ to $<65 \mathrm{~mm}$ and $>65 \mathrm{~mm}$ of peach genotypes in the city of Pelotas in 2016 (A) and 2017 (B), Rio Grande do Sul, Brazil. Brazil.

In 2017 harvest there were no significant differences for production per plant and estimated production between the thinning methods used (Table 2). However, there was a higher yield in the 'Cascata 1513' selection (Table 2), which although presenting fruits with the lowest average mass, also presented significantly higher number of fruits (Table 3). According to Ferreira et al. (2018) 'Cascata 1513' selection has higher yield potential, with higher yield and number of fruits compared to 'Cascata 1067' selection. This variation in yield between cultivars is common in orchards (SOUZA et al., 2013; FERREIRA et al., 2018).
'Cascata 1513' selection, in both harvests, produced the largest number of fruits per plant, but with smaller mass (Table 3) and smaller diameter (Figure 2). Increasing the number of fruits per plant reduces the source/drain ratio, contributing to the production of smaller fruits with low commercial value. In plants with high fruit load the growth of branches and fruits is limited (BUSSI et al., 2009). 
The number and average mass of fruits were not significantly influenced by peaches mechanical thinning, and this information was verified in both harvests (Table 3). These results corroborate with Martin et al. (2010), who found that mechanical flower thinning in peach trees does not change the number of fruits per plant. In general, it can be observed that the productive indexes of peach trees are more affected by genotype than by thinning method. Therefore, we verified the efficiency of the equipment tested in this study in reducing the number of flowers, but without being the limiting factor in productivity.
In both harvests, the highest percentage of smaller fruits $(<55 \mathrm{~mm})$ was observed in plants that were thinned with the Carpa Electro ${ }^{\circledR}$ equipment (Figure 3). It is noteworthy that these fruits have low commercial value due to their size. The mechanically thinned plants with the trimmer presented satisfactory results in relation to the diameter of the fruits, since they presented smaller percentages of small fruits $(<55 \mathrm{~mm})$ and larger percentages of larger fruits $(>65 \mathrm{~mm})$ in relation to manual thinning, in the two evaluated harvests.
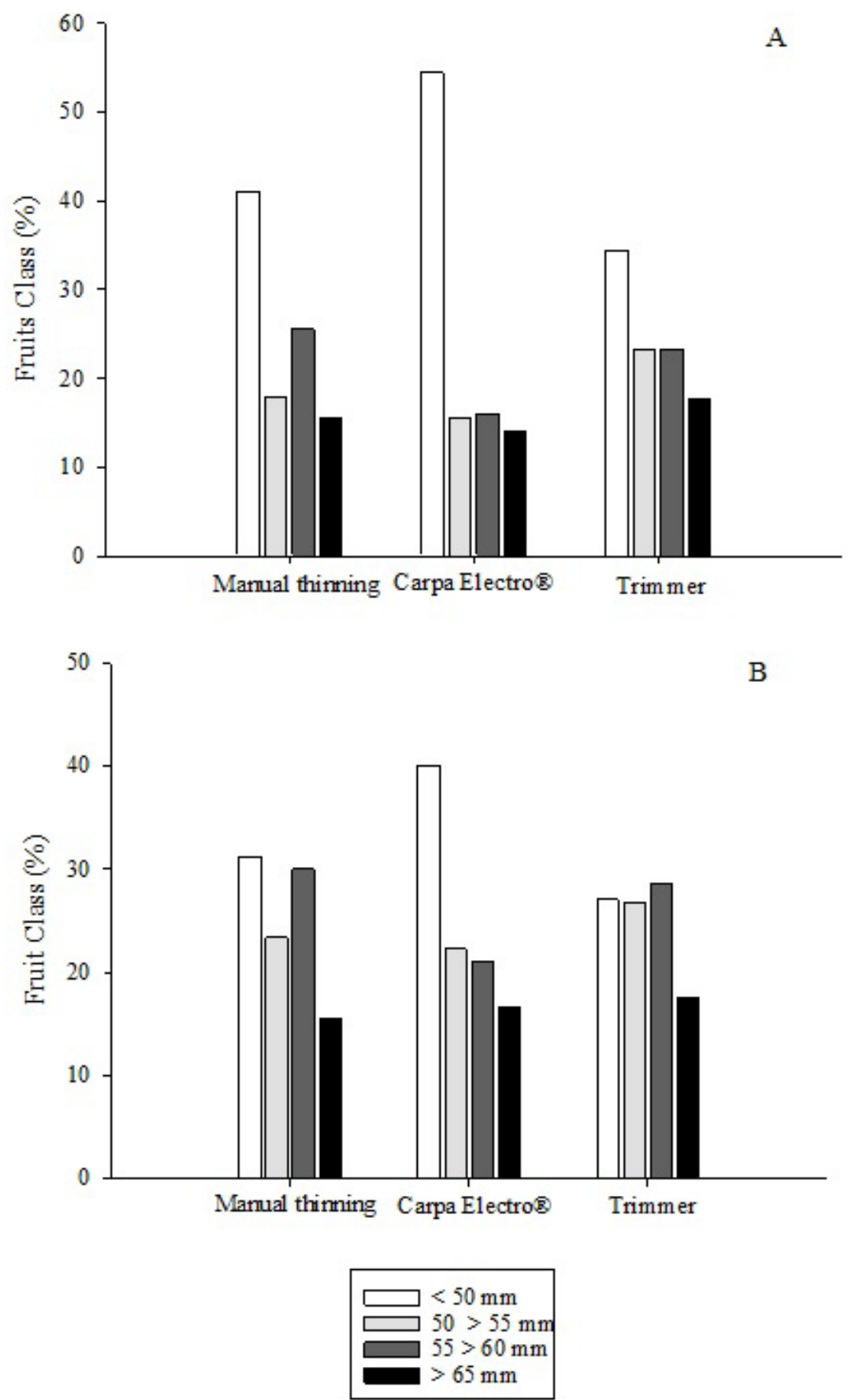

Figure 3 - Fruits Class by diameter $<55 \mathrm{~mm}, 55 \mathrm{~mm}$ to $<60 \mathrm{~mm}, 60 \mathrm{~mm}$ to $<65 \mathrm{~mm}$ and $>65 \mathrm{~mm}$ of peach genotypes submitted to mechanical flower thinning with different equipment and manual fruit thinning in the city of Pelotas in 2016 (A) and 2017 (B), Rio Grande do Sul, Brazil. 
Regarding the time spent on thinning, it was observed that the average time required was 2 and 3 minutes per plant for the operations performed with the trimmer and Carpa Electro ${ }^{\circledR}$ equipment, respectively. However, in the thinning done manually the average time was 8 minutes per plant. Therefore, mechanical thinning represents a reduction of approximately $70 \%$ of the time allocated to each plant for the practice of fruits thinning on peach trees. The reduction in time reflects the reduced need for labor, and consequently lower costs with this operation. These results corroborate with those found by Martin et al. (2010), Martin-Gorriz et al. (2011) and Miller et al. (2011) who verified that mechanical thinning on peach trees reduces the total working time.

\section{Conclusion}

Peach production is affected by mechanical flower thinning.

Carpa Electro ${ }^{\circledR}$ and trimmer equipment are efficient to perform mechanical flower thinning and to reduce the time of its execution in peach trees.

Mechanically thinned plants with the trimmer equipment provides larger diameter fruits.

\section{Acknowledgment}

The authors would like to the National Council for Scientific and Technological Development (CNPq) and Coordination for the Improvement of Higher Education Personnel (Capes) for granting of the scholarships and also EMBRAPA for the support in infrastructure and logistics for the execution of this study.

\section{References}

BARRETO, C.F.; NAVROSKI, R.; ZANDONÁ, R.R.; FARIAS, R.M.; MALGARIM, .B.; MELLO-FARIAS, P.C. Effect of chemical thinning using 6-benzyladenine (BA) on Maciel peach (Prunus persica L.). Australian Journal of Crop Science, Lismore, v.12, n.6, p.980-984, 2018 .

BUSSI, C.; LESCOURRET, F.; GENARD, M. Effects of thinning and pruning on shoot and fruit growths of girdled fruit-bearing shoots in two peach tree cultivars ('Big Top and Alexandra'). European Journal of Horticultural Science, Stuttgart, v. 74, n.3, p.97-102, 2009.
EL-BORAY, M.S.; SHALAN, A.M.; KHOURI, Z.M. Effect of different thinning techniques on fruit set, leaf area, yield and fruit quality parameters of Prunus persica L. Batsch cv. Florida Prince. Trends in Horticultural Research, Tustin, v.3, n.1, p.1-13, 2012.

FARIAS, R. de M.; MARTINS, C.R.; BARRETO, C.F.; GIOVANAZ, M.A.; MALGARIM, M.B.; MELLOFARIAS, P. Time of metamitron application and concentration in the chemical thinning of 'Maciel' peach. Revista Brasileira de Fruticultura, Jaboticabal, v.41, n.4, 2019.

FERREIRA, D. F. Sisvar: a Guide for its Bootstrap procedures in multiple comparisons. Ciência e Agrotecnologia, Lavras, v.38, n.2, p. 109-112, 2014.

FERREIRA, L.V..; PICOLOTTO, L.; PEREIRA, I.S.; SCHMITZ, J.D.; ANTUNES, L.E.C. Nitrogen fertilization in consecutive cycles and its impact on high-density peach crops. Pesquisa Agropecuária Brasileira, Brasília, DF, v.53, n.2, p.172-181, 2018.

GIOVANAZ, M. A.; FACHINELLO, J. C.; SPAGNOL, D.; WEBER, D.; CARRA, B. Gibberellic acid reduces flowering and time of manual thinning in 'Maciel' peach trees. Revista Brasileira de Fruticultura, Jaboticabal, v. 38, n.2, p.e-692, 2016.

MARTIN, B.; TORREGROSA, A.; GARCIA BRUNTON, J. Post-bloom thinning of peaches for canning with hand-held mechanical devices. Scientia Horticulturae, Amsterdam, v.125, n.4, p.658 - 665, 2010.

MARTIN-GORRIZ, B.; GARCIA-BRUTON, J.; TORREGROSA, A. Feasibility of peach bloom thinning with hand-held mechanical devices. Scientia Horticulturae, Amsterdam, v.129, n.1, p.91-97, 2011.

McARTNEY, S.J.; OBERMILLER, J.D.; ARELLANO, C. Comparison of the effects of metamitron on chlorophyll fluorescence and fruit set in apple and peach. HortScience, Alexandria, v.47, n.4, p.509-514, 2012.

MILLER, S.; SCHUPP, J.R.; BAYGHER, T.A.; WOLFORD, S.C. Performance of mechanical thinners for bloom or green fruit thinning in peaches. Hortscience, Alexandria, v. 46, n.1, p. 43-51, 2011.

OLIVEIRA P.D. DE.; MARODIN, G.A.B., ALMEIDA, G.K. DE A.; GONZATTO, M.P.; DARDE, D.C. Heading of shoots and hand thinning of flowers and fruits on 'BRS Kampai' peach trees. Pesquisa Agropecuária Brasileira, Brasília, DF, v.52, n.11, p.1006-1016, 2017. 
PEREIRA, J.F.M.; RASEIRA, A. Raleio. In: RASEIRA, M.C.B.; PEREIRA, J.F.M.; CARVALHO, F.L.C. (Ed.). Pessegueiro. Brasília, DF: Embrapa, 2014. p.309-327.

SAUERTEIG, K.A.; CLINE, J.A. Mechanical blossom thinning of 'Allstar' peaches influences yield and quality. Scientia Horticulturae, Amsterdam, v.160, p.243-250, 2013.

SCHUPP, J.J.; BAUGHER, T.; AUXT, MILLER, S.S.; HARSH, R.M.; LESSER, K.M. Mechanical thinning of peach and apple trees reduces labor input and increase fruit size. Horticulture Technology, Alexandria, v. 18, n.4, p.660-670, 2008.
SIMÕES, M.P. et al. Monda mecânica de flores com equipamento electro'flor em pessegueiros da cultivar 'Rich Lady'. Revista de Ciências Agrárias, Lisboa, v. 363, n.3, p. 297-302, 2013.

SOUZA, F.B.M. de; ALVARENGA, Â.A.; PIO, R.; GONÇALVES, E.D.; PATTO, L.S. Produção e qualidade dos frutos de cultivares e seleções de pessegueiro na Serra da Mantiqueira. Bragantia, Campinas, v.72, n. 2, p.133139, 2013. 